\title{
STRATEGI KOMUNIKASI DINAS PEMUDA, OLAHRAGA, KEBUDAYAAN DAN PARIWISATA DALAM MENINGKATKAN PARIWISATA DI KABUPATEN BANYUMAS
}

\author{
Prabawati Yusandra Maudyakasih ${ }^{1}$, Reni Nuraeni ${ }^{2}$ \\ ${ }^{1,2}$ Program Studi Ilmu Komunikasi, Fakultas Komunikasi dan Bisnis, Universitas Telkom \\ Email: ${ }^{1}$ prabawati.yusandra@gmail.com, ${ }^{2}$ rezn_ns@yahoo.com
}

\begin{abstract}
ABSTRAK
Kabupaten Banyumas memiliki banyak potensi wisata untuk dibangun dan dikembangkan menjadi daerah wisata dan festival kebudayaan. Untuk itu diperlukan strategi komunikasi untuk merencanakan dan manajemen komunikasi agar masyarakat datang berwisata ke Kabupaten Banyumas. Metodologi yang digunakan adalah kualitatif deskriptif. Penelitian ini bertujuan mendeskripsikan dan menganalisis strategi komunikasi dalam meningkatkan pariwisata di Kabupaten Banyumas. Objek penelitian dilakukan pada DINPORABUDPAR Kabupaten Banyumas. Penelitian ini menggunakan model strategi komunikasi menurut Cangara. Paradigma penelitian yang digunakan merupakan paradigma konstruktivis. Hasil penelitian menemukan bahwa DINPORABUDPAR Kabupaten Banyumas mencari fakta mengenai lingkungan atau latar belakang masyarakat kemudian melakukan riset bedasarkan teori-teori yang ada; membentuk tim PPID dan mengikutsertakan para Blogger lokal untuk ikut mempromosikan wisata yang ada melalui media online; memposting konten mengenai wisata yang ada di Kabupaten Banyumas; mengukur jumlah wisatawan yang datang disetiap objek wisata dan event; setiap objek wisata memberikan laporan untuk dilakukan perekapan data untuk laporan jumlah wisatawan di setiap tahunnya.
\end{abstract}

Kata kunci: Strategi Komunikasi, Pariwisata, Perencanaan Komunikasi.

\begin{abstract}
Banyumas Regency has a lot of tourism potential to be built and developed into tourist areas and cultural festivals. For this reason, a communication strategy is needed to plan and manage communications so that people come touring Banyumas Regency. The methodology used is qualitative descriptive. This study aims to describe and analyze communication strategies in increasing tourism in Banyumas Regency. The object of the study was conducted at DINPORABUDPAR Banyumas Regency. This study uses a communication strategy model according to Cangara. The research paradigm used is a constructivist paradigm. The results of the study found that DINPORABUDPAR Banyumas Regency looked for facts about the environment or community background and then conducted research based on existing theories; forming a PPID team and involving local Bloggers to participate in promoting existing tourism through online media; post content about tours in Banyumas Regency; measure the number of tourists coming to each tourist attraction and event; each tourist object provides a report for data recording to report the number of tourists in each year.
\end{abstract}

Keywords: Communication Strategy, Tourism, Communication Planning.

\section{PENDAHULUAN}

\subsection{LatarBelakang}

Indonesia terkenal akan kekayaan dan keindahan alamnya. Namun, pesona itu belum terlalu diketahui negara lain. Berdasarkan Undang-Undang No. 10 Tahun 2009, Pariwisata adalah berbagai macam kegiatan wisata dan didukung berbagai fasilitas serta layanan yang disediakan oleh masyarakat, pengusaha, Pemerintah, dan Pemerintah Daerah. Bagi Indonesia, pariwisata memiliki kontribusi yang signifikan dalam pembangunan ekonomi nasional sebagai instrumen peningkatan perolehan devisa. Sektor pariwisata akan menjadi sektor penyumbang devisa negara yang paling unggul pada tahun 2019. Namun belum semua daerah di Indonesia optimal mengembangkan sektor pariwisatanya.

Provinsi Jawa Tengah sebagai salah satu provinsi di Indonesia yang menyimpan banyak potensi pariwisata, seperti keindahan alammya yang mempesona, beragam tradisi budaya yang menarik, serta bermacam-macam jenis makanan tradisional dengan cita rasa yang khas yang tersebar di 35 Kabupaten/Kota di Jawa Tengah. Banyak potensi pariwisata di Jawa Tengah yang terabaikan atau belum terjamah karena kurangnya promosi dan inovasi. Kabupaten Banyumas salah satu daerah tujuan wisata di Jawa Tengah optimis kunjungan wisatawan terus meningkat setiap tahunnya. Wisata alam, budaya dan meningkatnya mahasiswa yang menempuh pendidikan di sana 
menjadi potensi yang menunjang jumlah kunjungan wisatawan berkunjung ke Kabupaten Banyumas.

Kabupaten Banyumas memiliki sejumlah destinasi wisata kebudayaan dan seni diantaranya Baturaden, Museum Wayang, Taman Panglima Soedirman, Taman Andhang Pangrenan, Taman Bale Kemambang, Wisata Husada Kalibacin, Masjid Saka Tunggal, Curug Cipendok, Curug Gede, Curug Ceheng, Small World, dan wisata yang dikelola Palawi seperti Kebun Raya Baturraden, Pancuran Pitu, Bumi Perkemahan dan beberapa obyek wisata lainnya. Dinas Pemuda Olahraga Kebudayaan Pariwisata Banyumas akan berfokus pada untuk mempromosikan pariwisata daerahnya. Masih banyak lokawisata di Banyumas yang belum dikenal masyarakat luas. Hal itu kemungkinan disebabkan kurangnya promosi dari beberapa pihak terkait. Selain itu, rendahnya jumlah wisatawan asing, lama tinggal, kurangnya aksesbilitas, juga kurangnya sarana prasarana di objek wisata.

Dinas Pemuda, Olahraga, Kebudayaan, dan Pariwisata (Dinporabudpar) Kabupaten Banyumas, menyatakan banyaknya tempat wisata di Banyumas yang mulai mengalami perkembangan, masih jarang diketahui oleh masyarakat di luar Banyumas. Dan kebanyakan masyarakat tersebut, hanya mengetahui Baturraden sebagai lokawisata yang ada di Kabupaten Banyumas. Oleh karena itu, dalam mempromosikan kepariwisataan di Kabupaten Banyumas dibutuhkan suatu strategi komunikasi yang bertujuan untuk mengetahui efektivitas promosi yang dilakukan Dinas Pariwisata Kabupaten Banyumas dalam meningkatkan pariwisata.

Berdasarkan latar belakang tersebut peneliti tertarik untuk mengkaji tentang strategi komunikasi Dinas Pemudan, Olahraga, Kebudayaan dan Pariwisata Kabupaten Banyumas dalam meningkatkan pariwisata. Dengan demikian, peneliti mengangkat judul skripsi yaitu "Strategi Komunikasi Dinas Pemuda, Olahraga, Kebudayaan dan Pariwisata Dalam Meningkatkan Pariwisata di Kabupaten Banyumas".

\subsection{TujuanPenelitian}

Tujuan dari penelitian ini yaitu untuk mengetahui bagaimana strategi komunikasi Dinas Pemuda, Olahraga, Kebudayaan dan Pariwisata dalam meningkatkan pariwisata di Kabupaten Banyumas.

kajian dibidang Ilmu Komunikasi khususnya mengenai strategi komunikasi.

- Bagi Peneliti

Hasil penelitian ini diharapkan memberikan pengetahuan, pengalamandan pemahaman yang lebih mendalam kepada peneliti mengenai stra- tegikomunikasi Dinas Pemudan, Olahraga, Kebudayaan dan Pariwisata dalam meningkatkan pariwisata di Kabupaten Banyumas.

\section{TINJAUAN PUSTAKA}

\subsection{Komunikasi}

Dalam Cangara (2014:22), Rogers dan D. Lawrence Kincaid berpendapat bahwa komunikasi adalah suatu proses dimana dua orang atau lebih membentuk atau melakukan pertukaran informasi dengan satu sama lainnya, yang pada gilirannya akan tiba pada saling pengertian yang mendalam.

\subsection{Strategi Komunikasi}

Strategi komunikasi adalah kiat atau taktik yang bias dilakukan dalam melaksanakan perencanaan komunikasi. Menurut Cangara (2013:76), strategi komunikasi menggunakan model perencanaan komunikasi lima langkah menggunakan lima tahapan yaitu Research, Plan, Execute, Measure, dan Report.

Komunikasi merupakan suatu proses yang rumit. Dalam rangka menyusun strategi komunikasi diperlukan suatu pemikiran dengan memperhitungkan komponen-komponen komunikasi, factor pendukung dan penghambat komunikasi yaitu:

1. Sasaran Komunikasi

2. Penyusunan Pesan / Strategi Pesan

3. Menetapkan Metode

4. Pemilihan Media Komunikasi/Strategi Media

5. Komunikator/Strategi Komunikator.

\subsection{Tujuan Strategi Komunikasi}

Liliweri (2011:248) dalam bukunya Komunikasi Serba Ada Serba Makna, menjelaskan tujuan strategi komuikasi yaitu:

1. Memberitahu (Announcing)

2. Memotivasi (Motivating)

3. Mendidik (Educating)

4. Menyebarkan Informasi (Informing)

5. Mendukung Pembuatan Keputusan (Supporting Decision Making)

\subsection{Pariwisata}

Prof. Salah Wahab (Oka A Yoeti, 1996; 116), menjelaskan Pariwisata sebagai suatu aktivitas manusia yang dilakukan secara sadar yang mendapat pelayanan secara bergantian diantara orang-orang dalam suatu negara itu sendiri atau di luar negeri, meliputi 
pendiaman orang-orang dari daerah lain untuk sementara waktu mencari kepuasan yang beraneka ragam dan berbeda dengan apa yang dialaminya, dimana ia memperoleh pekerjaan tetap.

\section{METODE PENELITIAN}

Penelitian strategi komunikasi strategi komunikasi Dinas Pemudan, Olahraga, Kebudayaan dan Pariwisata Kabupaten Banyumas dalam meningkatkan pariwisata ini menggunakan paradigma konstruktivisme. Menurut Elvinaro dan Bambang (2009: 154), konstruktivisme adalah salah satu filsafat pengetahuan yang menekankan bahwa pengetahuan kita adalah konstruksi (bentukan) kita sendiri (Von Glasersfeld dalam Bettencourt, 1989 dan Matthews 1994).

Penelitian ini menggunakan metode penelitian kualitatif. Menurut Sugiyono (2016:1), metode penelitian kualitatif adalah metode penelitian yang digunakan untuk meneliti pada kondisi objek yang alamiah, (sebagai lawannya adalah eksperimen) dimana peneliti adalah sebagai instrument kunci, teknik pengumpulan data dilakukan secara trianggulasi (gabungan), analisis data bersifat induktif, dan hasil penelitian kualitatif lebih menekankan makna dari pada generalisasi. Penelitian ini menggunakan metode kualitatif dengan wawancara mendalam kepada narasumber yang terlibat langsung dalam penyusunan dan pembuatan strategi komunikasi.

Wawancara yang dilakukan melibatkan ahli dalam bidang strategi komunikasi dan pihak yang menjadi target audiens dari strategi komunikasi. Teknik penentuan informan pada penelitian ini menggunakan purposive sampling. Menurut Sugiyono (2016:5354), purposive sampling adalah teknik pengambilan sampel sumber data dengan pertimbangan tertentu sehingga memudahkan peneliti menjelajah objek/ situasi sosial yang diteliti. Kriteria informan utama dalam subjek penelitian ini antara lain:

1. Mengetahui strategi yang dilakukan oleh Dinas Pemuda, Olahraga, Pariwisata dan Kebudayaan dalam meningkatkan pariwisata di Kabupaten Banyumas.

2. Mengetahui terlibat dalam meningkatkan pariwisata di Kabupaten Banyumas.

3. Berada dalam lingkupDinas Pemuda, Olahraga, Pariwisata dan Kebudayaan Kabupaten Banyumas.

Kriteria informan ahli:

1. Ahli Pakar yang bergerak di Bidang Strategi Komunikasi.
Tabel 1. Informan Penelitian

\begin{tabular}{|c|c|c|}
\hline Nama & Jabatan & Keterangan \\
\hline \multirow{4}{*}{$\begin{array}{l}\text { 1. D S Dajtmiko, } \\
\text { S.Sos.,M.Si }\end{array}$} & Kepala Bidang & \multirow{4}{*}{$\begin{array}{l}\text { Informan } \\
\text { Utama }\end{array}$} \\
\hline & Pariwisata & \\
\hline & DISPORABUDPAR & \\
\hline & Kabupaten Banyumas & \\
\hline \multirow[t]{4}{*}{ 2. NunusDanianto } & Kepala Seksi Promosi & \multirow{4}{*}{$\begin{array}{c}\text { Informan } \\
\text { Utama }\end{array}$} \\
\hline & $\begin{array}{l}\text { dan Pemasaran Pari- } \\
\text { wisata }\end{array}$ & \\
\hline & DISPORABUDPAR & \\
\hline & Kabupaten Banyumas & \\
\hline \multirow{3}{*}{$\begin{array}{l}\text { 3. Dr. Mite } \\
\text { Setiansah, M.Si }\end{array}$} & Pakar Komunikasi & \multirow[t]{3}{*}{ Informan Ahli } \\
\hline & Universitas Jendral & \\
\hline & Soedirman & \\
\hline
\end{tabular}

Metode ini menghasilkan penemuan data atau informasi yang tidak dapat dicapai dengan menggunakan prosedur kuantitatif. Subjek dari penelitian ini adalah pihak-pihak bagian Dinas Pemuda, Olahraga, Pariwisata, dan Kebudayaan Kabupaten Banyumas dan pihak lain yang memiliki wewenang dalam pembuatan strategi komunikasi. Lokasi penelitian dilakukan di Dinas Pemuda, Olahraga, Pariwisata, dan Kebudayaan Kabupaten Banyumas Jl. Prof. Dr. Soeharso No. 45, Purwokerto, Purwokerto Lor, Purwokerto Tim., Kabupaten Banyumas, Jawa Tengah 53114. Lokasi dipilih berdasarkan latar belakang penelitian.

Penelitian dengan pendekatan kualitatif, maka tektik pengumpulan data yang relatif tepat adalah interview. Menurut Sugiyono (2016:72) Wawancara digunakan sebagai teknik pengumpulan data apabila peneliti ingin melakukan studi pendahuluan untuk menemukan permasalahan yang harus diteliti, tetapi juga apabila peneliti ingin mengetahui hal-hal dari responden yang lebih mendalam.

Dalam penelitian ini penulis menggunakan jenis wawancara semiterstruktur. Jenis wawancara ini sudah dapat dikategorikan sebagai in-depth interview, dimana dalam pelaksanaannya lebih bebas bila dibandingkan dengan wawancara terstruktur. Tujuan dari wawancara jenis ini adalah untuk menemukan permasalahan secara lebih terbuka, dimana pihak yang diajak wawancara diminta pendapat, dan ide-idenya. Dalam hal ini, peneliti dalam melakukan pengumpulan data menyatakan terus terang atau tersamar kepada sumber data, bahwa peneliti sedang melakukan penelitian. Jadi mereka yang diteliti mengetahui sejak awal sampai akhir tentang aktivitas peneliti. Tetapi dalam suatu saat peneliti juga tidak terus terang atau tersamar dalam observasi, hal ini untuk menghindari kalau suatu data yang dicari merupakan data yang masih dirahasiakan. Kemungkinan kalau dilakukan dengan terus terang, maka peneliti tidak akan diijinkan untuk melakukan observasi (Sugiyono, 2014: 66). 


\section{HASIL PENELITIAN}

Pada bab ini, peneliti menjelaskan bagaimana hasil dan pembahasan yang telah peneliti lakukan mengacu pada identifikasi masalah.Hasil temuan tersebut dideskripsikan sesuai dengan fokus dan indentifikasi penelitian, yaitu mengenai strategi komunikasi serta tahapan-tahapan dalam strategi komunikasi. Hasil penelitian berdasarkan wawancara mendalam dengan informan yang memiliki kriteria sesuai dengan yang dibutuhkan dalam penelitian. Dalam penelitian ini penulis akan menganalisa tahapan dalam strategi komunikasi kedalam sub bab hasil penelitian dan pembahasan.

\subsection{Tahapan Strategi Komunikasi Dinas Pemuda, Olahraga, Kebudayaan dan Pariwisata Dalam Meningkatkan Pariwisata di Kabupaten Banyumas}

Strategi komunikasi adalah kiat atau taktik yang bisa dilakukan dalam melaksanakan perencanaan komunikasi. Penelitian ini menggunakan model perencanaan komunikasi lima langkah yang terdiri atas lima tahapan yaitu Research, Plan, Execute, Measure, dan Report. Penulis akan menjabarkan lima tahapan model perencanaan komunikasi lima langkah yang digunakan dalam strategi komunikasi wisata Dinas Pemuda, Olahraga, Kebudayaan dan Pariwisata Dalam Meningkatkan Pariwisata di Kabupaten Banyumas sebagai berikut:

1. Penelitian (Research)

Dalam tahap research Dinas Pemuda, Olahraga, Kebudayaan dan Pariwisata Kabupaten Banyumas menggunakan riset terlebih dahulu sebelum melakukan perencanaan komunikasi. Namun riset yang dilakukan adalah berupa riset mengenai permasalahan komunikasi yang ada di masyarakat, karena setiap orang memiliki penalaran Bahasa yang berbeda karena latar belakang yang berbeda. Latar belakang yang di maksud adalah latar belakang masyarakat mengenai jenjang pendidikan masyarakat dan pemahamannya tentang komunikasi. Contohnya seperti perbedaan komunikasi pada tukang batu dengan pelajar, pasti akan memiliki pemahaman bahasa yang berbeda. Dalam melakukan risetnya, Dinas Pemuda, Olahraga, Kebudayaan dan Pariwisata Kabupaten Banyumas menggunakan teori-teori yang ada. Dinas Pemuda, Olahraga, Kebudayaan dan Pariwisata Kabupaten Banyumas bahwa perlu melakukan riset atau fact finding untuk menentukan rencana dari strategi komunikasi karena strategi komunikasi adalah taktik untuk memenang- kan persaingan. Persaingan yang dimaksud adalah persaingan komunikasi dalam meningkatkan pariwisata.

2. Perencanaan (Plan)

Tahap plan yang dilakukan Dinas Pemuda, Olahraga, Kebudayaan dan Pariwisata Kabupaten Banyumas adalah menentukan sumber atau komunikator, pesan, konten, media, target sasaran, dan efek. Dinas Pemuda, Olahraga, Kebudayaan dan Pariwisata Kabupaten Banyumas membentuk tim PPID dan mengikutsertakan para Blogger local untuk ikut mempromosikan wisata yang ada melalui media online. Komunikator yang digunakan adalah dari masyarakat yaitu aliansi pariwisata. Pesan yang digunakan berisi tentang ajakan untuk mengunjungi objek wisatadan festival yang diselenggarakan. Konten dalam hal ini berisi seputar objek wisatadan festival-festival yang ada. Media yang digunakan yaitu website, leaflet, Instagram, dan pemberitaan di media serta mengikutsertakan blogger untuk ikut memberitakan objek wisatadan festival yang akan di selenggarakan. Target sasaran seluruh warga di wilayah Kabupaten Banyumas. Efek yang diharapkan adalah wisatawan bisa long stay di Kabupaten Banyumas.

3. Pelaksanaan (Execute)

Seperti yang sudah dijelaskan pada tahap plan, media promosi yang digunakan menggunakan website, leaflet, pemberitaan di portal berita, menggunakan blogger sebagai media promosi, dan media social seperti Instagram. Pada tahap execute, seluruh perencanaan komunikasi terlaksana sesuai dengan yang direncanakan. Kemudian memposting konten mengenai wisata yang ada di Kabupaten Banyumas. Konten dan media yang dilakukan untuk menjangkau target sasaran dan untuk mencapai tujuan perencanaan komunikasi, yaitu target sasaran datang berwisata di Kabupaten Banyumas.

4. Pengukuran (Measure)

Tahap measure Dinas Pemuda, Olahraga, Kebudayaan dan Pariwisata Kabupaten Banyumas yaitu dengan menggunakan indikator penilaian yang dilihat berdasarkan jumlah wisatawan yang datang disetiap objek wisata dan event. Dalam melakukan monitoring, Dinas Pemuda, Olahraga, Kebudayaan dan Pariwisata Kabupaten Banyumas mengatakan belum memiliki metode sendiri untuk melakukan hal tersebut. Dinas Pemuda, Olahraga, Kebudayaan dan Pariwisata Kabupaten Banyumas juga belum memiliki tim khusus untuk melakukan survey kepuasan wisatawan secara bertahap untuk mengurangi kemungkinan adanya penurunan jumlah wisatawan yang datang. Yang dilakukan masihlah menggunakan manual. 


\section{Pengukuran (Measure)}

Tahap report Dinas Pemuda, Olahraga, Kebudayaan dan Pariwisata Kabupaten Banyumas yaitu dengan setiap objek wisata memberikan laporan kemudian diberikan kepada Dinas Pemuda, Olahraga, Pariwisata, dan Kebudayaan Kabupaten Banyumas untuk dilakukan perekapan data secara keseluruhan dari objek wisata yang ada dan dibuat sebuah laporan jumlah wisatawan di setiap tahunnya. Selain itu, disetiap event yang terlaksana juga adanya evaluasi berupa laporan hasil kegiatan.

\section{PEMBAHASAN}

Banyak potensi pariwisata di Jawa Tengah yang terabaikan atau belum terjamah karena kurangnya promosi dan inovasi. Senada dengan keadaan di Jateng, Banyumas juga mengalami hal serupa. Kabupaten Banyumas salah satu daerah tujuan wisata di Jawa Tengah optimis kunjungan wisatawan terus meningkat setiap tahunnya. Masih banyak lokawisata di Banyumas yang belum dikenal masyarakat luas. Hal itu kemungkinan disebabkan kurangnya promosi dari beberapa pihak terkait. Dalam pembuatan strategi komunikasi Dinas Pemuda, Olahraga, Kebudayaan dan Pariwisata Kabupaten Banyumas membuat dan mengumpulkan data yang akan digunakan untuk melakukan perencanaan komunikasi. Pada Sub-bab ini, penulis menganalisa strategi komunikasi Dinas Pemuda, Olahraga, Kebudayaan dan Pariwisata Kabupaten Banyumas berdasarkan unit analisis dan fokus penelitian yaitu dengan melihat tahapantahapan yang digunakan dalam strategi komunikasi.

\subsection{Tahapan Strategi Komunikasi Dinas Pemuda, Olahraga, Kebudayaan dan Pariwisata Kabu- paten Banyumas}

\section{Penelitian (Research)}

Berdasarkan pernyataan dari pihakDinas Pemuda, Olahraga, Kebudayaan dan Pariwisata Kabupaten Banyumas, bahwa mereka melakukan riset awal dengan mencari fakta mengenai lingkungan atau latar belakang masyarakat kemudian melakukan riset bedasarkan teori-teori yang ada dan juga melihat dari hasil evaluasi dari setiap event pariwisata yang dilaksanakan melihat data hasil laporan jumlah wisatawan di setiap tahunnya.

Dinas Pemuda, Olahraga, Kebudayaan dan Pariwisata Kabupaten Banyumas sebelumnya sudah melakukan strategi komunikasi. Strategi komunikasi tersebut kurang efektif dikarenakan adanya masalah komunikasi yang belum bisa dipahami semua orang khususnya di Kabupaten Banyumas. Namun riset yang dilakukan adalah berupa riset mengenai permasalahan komunikasi yang ada di masyarakat, karena setiap orang memiliki penalaran Bahasa yang berbeda karena latar belakang yang berbeda. Latar belakang yang di maksud adalah latar belakang masyarakat mengenai jenjang pendidikan masyarakat dan pemahamannya tentang komunikasi. Contohnya seperti perbedaan komunikasi pada tukang batu dengan pelajar, pasti akan memiliki pemahaman bahasa yang berbeda. Dalam melakukan risetnya, Dinas Pemuda, Olahraga, Kebudayaan dan Pariwisata Kabupaten Banyumas menggunakan teori-teori yang ada. Dinas Pemuda, Olahraga, Kebudayaan dan Pariwisata Kabupaten Banyumas bahwa perlu melakukan riset atau fact finding untuk menentukan rencana dari strategi komunikasi karena strategi komunikasi adalah taktik untuk memenangkan persaingan. Persaingan yang dimaksud adalah persaingan komunikasi dalam meningkatkan pariwisata.

2. Perencanaan (Plan)

Setelah mengetahui tahapan research, dapat dilihat bahwa dalam meningkatkan pariwisata Dinas Pemuda, Olahraga, Kebudayaan dan Pariwisata Kabupaten Banyumas perlu membuat rancangan komunikasi agar memudahkan terlaksananya tujuan dari peningkatnya pariwisata. Setelah itu, perlu mengambil tindakan untuk menggunakan berbagai macam media, termasuk membentuk tim PPID dan para Blogger lokal. Perencanaan komunikasi yang disusun terdapat komponen komunikasi, diantaranya sumber, pesan, media, penerima, dan pengaruh atau efek.

Dinas Pemuda, Olahraga, Kebudayaan dan Pariwisata Kabupaten Banyumas menentukan sumber atau komunikator, pesan, konten, media, target sasaran, dan efek. Dinas Pemuda, Olahraga, Pariwisata, dan Kebudayaan Kabupaten Banyumas membentuk tim PPID dan mengikutsertakan para Blogger local untuk ikut mempromosikan wisata yang ada melalui media online. Komunikator yang digunakan adalah dari masyarakat yaitu aliansi pariwisata. Pesan yang digunakan berisi tentang ajakan untuk mengunjungi objek wisata dan festival yang diselenggarakan. Konten dalam hal ini berisi seputar objek wisata dan festivalfestival yang ada. Media yang digunakan yaitu website, leaflet, Instagram, dan pemberitaan di media serta mengikutsertakan blogger untuk ikut memberitakan objek wisata dan festival yang akan di selenggarakan. Target sasaran seluruh warga di wilayah Kabupaten Banyumas. Efek yang di- 
harapkan adalah wisatawan bias long stay di Kabupaten Banyumas.

3. Pelaksanaan (Execute)

Tahap pelaksanaan (execute) adalah tindakan yang diambil dalam rangka implementasi perencanaan komunikasi yang telah dibuat. Implementasi dari perencanaan yang telah dibuat oleh Dinas Pemuda, Olahraga, Kebudayaan dan Pariwisata Kabupaten Banyumas melaksanakan semua yang sudah dirancang pada perencanaan komunikasi. Media yang digunakan yaitu Instagram, Website, dan Blog serta media alternatif seperti, leaflet, brosur. Peneliti melihat dari media-media tersebut cukup aktif dalam memposting konten mengenai wisata yang ada di Kabupaten Banyumas. Konten dan media yang dilakukan untuk menjangkau target sasaran dan untuk mencapai tujuan perencanaan komunikasi, yaitu target sasaran datang berwisata di Kabupaten Banyumas. Target sasaran sesuai dengan yang direncanakan, yaitu didominasi wisatawan yang membawa keluarga dan rekan-rekannya.

Tahap pelaksanaan komunikasi, tujuan akhir adalah untuk meningkatkan pariwisatakan bukan menyebarkan brosur, bukan meningkatkan postingan melainkan untuk meningkatkan jumlah kunjungan wisata, meningkatkan pendapatan masyarakat dari pariwisata. Tahap pelaksanaan dari perencanaan komunikasi ini memiliki fungsi yaitu menginformasikan kepada masyarakat mengenai wisata yang ada di Kabupaten Banyumas melalui media-media yang sudah digunakan. Dalam hal ini masyarakat menjadi penerima pesan yang telahdilakukan oleh Dinas Pemuda, Olahraga, Pariwisata, dan Kebudayaan.

4. Pengukuran (Measure)

Untuk pengukuran dari pelaksanaan komunikasi yang telah dilakukan, Dinas Pemuda, Olahraga, Kebudayaan dan Pariwisata Kabupaten Banyumas menggunakan indikator dilihat dari efek yang ditimbulkan yaitu jumlah pengunjung yang datang disetiap tempat wisata maupun festival. Dengan adanya tahap pengukuran, mampu membandingkan hasil yang didapat sudah atau belum dengan efek yang diharapkan pada tahap perencanaan. Dapat dilihat bahwa efek yang diharapkan yaitu membuat target sasaran datang ke Kabupaten Banyumas, sehingga meningkatkan jumlah wisatawan ke Kabupaten Banyumas. Hal ini juga selaras dengan tujuan komunikasi yaitu meningkatkan wisatawan ke Kabupaten Banyumas. Umpan balik dari target sasaran dapat dikatakan berhasil dilihat dari jumlah pengunjung wisata yang meningkat.Jumlah target sasaran yang ditetapkan oleh Dinas Pemuda, Olahraga, Kebudayaan dan Pariwisata Kabupaten Banyumas dalam meningkatkan pariwisata sudah melebihi jumlah target wisatawan yang sudah diperkirakan. Dalam melakukan monitoring, Dinas Pemuda, Olahraga, Kebudayaan dan Pariwisata Kabupaten Banyumas mengatakan belum memiliki metode sendiri untuk melakukan hal tersebut. Yang dilakukan masihlah menggunakan manual seperti melihat viewers dan followers di media social yang digunakan. Pihak Dinas Pemuda, Olahraga, Kebudayaan dan Pariwisata Kabupaten Banyumas dengan melakukan pengukuran terhadap jumlah pengunjung yang datang di setiap objek wisata maupun event sudah baik dilihat dari outcome yaitu meningkatnya jumlah wisatawan yang datang.

5. Pelaporan (Report)

Dinas Pemuda, Olahraga, Kebudayaan dan Pariwisata Kabupaten Banyumas melakukan evaluasi yaitu setiap objek wisata memberikan laporan kemudian diberikan kepada Kepala Dinas Pemuda, Olahraga, Kebudayaan dan Pariwisata Kabupaten Banyumas untuk dilakukan perekapan data secara keseluruhan dari objek wisata yang ada dan dibuat sebuah laporan jumlah wisatawan di setiap tahunnya. Selain itu, disetiap event yang terlaksana juga adanya evaluasi berupa laporan hasil kegiatan Laporan dari Dinas Pemuda, Olahraga, Kebudayaan dan Pariwisata Kabupaten Banyumas dapat digunakan sebagai data pada tahapan research dalam program perencanaan komunikasi selanjutnya.

\section{KESIMPULAN}

Berdasarkan hasil pembahasan dan analisis yang telah dipaparkan pada bab-bab sebelumnya, dapat disimpulkan bagaimana proses strategi komunikasi yang dilakukan olehDinas Pemuda, Olahraga, Kebudayaan dan Pariwisata Kabupaten Banyumas yaitu pada tahap pertama, Dinas Pemuda, Olahraga, Pariwisata, dan Kebudayaan Kabupaten Banyumas melakukan tahapan research dengan melakukan riset awal dengan mencari fakta mengenai lingkungan atau latar belakang masyarakat kemudian melakukan riset bedasarkan teori-teori yang ada. Latar belakang yang di maksud adalah latar belakang masyarakat mengenai jenjang pendidikan masyarakat dan pemahamannya tentang komunikasi. Tahap selanjutnya yaitu dengan membuat perancangan komunikasi pada tahap plan. Tahap plan yaitu dengan menentukan sumber atau komunikator, pesan, konten, media, target sasaran, dan efek. Dinas Pemuda, Olahraga, 
Pariwisata, dan Kebudayaan Kabupaten Banyumas membentuk tim PPID dan mengikutsertakan para Blogger local untuk ikut mempromosikan wisata yang ada melalui media online. Pada tahap execute, seluruh perencanaan komunikasi terlaksana sesuai dengan yang direncanakan. Kemudian memposting konten mengenai wisata yang ada di Kabupaten Banyumas. Konten dan media yang dilakukan untuk menjangkau target sasaran dan untuk mencapai tujuan perencanaan komunikasi, yaitu target sasaran datang berwisata di Kabupaten Banyumas. Media yang digunakan adalan Web, Blog, dan Instagram. Selain itu berita juga terdapat di surat kabar lokal mengenai wisata-wisata terbaru yang ada di Banyumas.Tahap measure yang dilakukan Dinas Pemuda, Olahraga, Kebudayaan dan Pariwisata Kabupaten Banyumas yaitu dengan menggunakan indikator penilaian yang dilihat berdasarkan jumlah wisatawan yang datang disetiap objek wisata dan event. Dalam melakukan pengukuran jumlah pengunjung menggunakan data kunjungan yaitu menggunakan tiket yang terjual di objek wisata. Tahap report atau pelaporan yang dilakukan oleh Dinas Pemuda, Olahraga, Kebudayaan dan Pariwisata Kabupaten Banyumas yaitu, setiap objek wisata memberikan laporan kemudian diberikan kepada Kepala Dinas Pemuda, Olahraga, Kebudayaan dan Pariwisata Kabupaten Banyumas untuk dilakukan perekapan data secara keseluruhan dari objek wisata yang ada dan dibuat sebuah laporan jumlah wisatawan di setiap tahunnya. Selain itu, disetiap event yang terlaksana juga adanya evaluasi berupa laporan hasil kegiatan.

\section{DAFTAR PUSTAKA}

Alo Liliweri. (2011). Komunikasi serba ada serba makna. Kencana: Jakarta

Ardianto, Elvinaro, \& Bambang, Q-Anees. (2009). Filsafat Ilmu Komunikasi. Bandung: Simbiosa Rekatama Media.

Cangara, Hafied. (2013). Perencanaan \& Strategi Komunikasi. Jakarta: PT. Raja Grafindo Persada

Effendi, Onong Uchjana. (2000). Ilmu Teori \& Filsafat Komunikasi, PT Citra Aditya Bakti, Bandung

Effendi, Onong Uchjana. (2002). Dinamika Komunikasi. PT. Remaja Rosdakarya, Bandung

Effendy, Onong Uchjana. (2003). Ilmu, Teori dan Filsafat Komunikasi. Bandung: Citra Aditya Bakti, Bandung

Effendy, Onong Uchjana. (2007). Ilmu Komunikasi Teori dan Praktek, Bandung: PT. Remaja Rosdakarya, Bandung

Fajar, Marhaeni. (2009). Ilmu Komunikasi Teori \& Praktek Edisi Pertama. Graha Ilmu, Yogyakarta.
Greenley, Gordon E. (2006). Perceptions of Marketing Strategy and Strategic Marketing in UK companies. Volume 1, 1993 - Issue 3.

Hallahan, Kirk, Holtzhausen, Derina, van Ruler B., dkk. (2007). Defining Strategic Communication, International Journal Of Strategic Communication, 1(1), 3-35.

Invernizzi, Emanuele \& Romenti, Stefania. (2011). Strategic Communication and Decision-Making Processes Toward the Communication Oriented Organisation. Academicus International Scientific Journal, issue 3, 12-27.

Mahrik, Ardilla. (2016). Strategi Komunikasi Dinas Komunikasi Informatika Kebudayaan Dan Kepariwisataan Dalam Meningkatkan Kunjungan Wisatawan Di Kabupaten Sinjai. Skripsi pada Universitas Hasanuddin Makassar: tidak dipublikasikan.

Marpaung, Beny OY. (2016). Communication Strategy Planning of Fisherman Kampung Medan Belawan as a Tourist Destination. Procedia Social and Behavioral Sciences Volume 234, Pages 344-352.

Meilisa, V.F. Strategi Komunikasi Dinas Pariwisata, Kepemudaandan Olahraga, Dan Kebudayaan Kabupaten Indragirhilir Dalam Menarik Minat Pengunjung Objek Wisata

Moleong, Lexy J. (2011). Metodologi Penelitian Kualitatif. Bandung: Remaja Rosdakarya

Mukarom, Zainal dan Muhibudin Wijaya Laksana. (2015). Manajemen Public Relation. Bandung: Pustaka Setia

Mulyana, Deddy. (2007). Ilmu Komunikasi Suatu Pengantar. Remaja Rosdakarya: Bandung Pantai Solop. JOM FISIP. Vol. 5 No. 1.

Pujileksono, Sugeng. (2015). Metode Penelitian Komunikasi Kualitatif. Malang: Intrans Publishing.

Ratnasari, Y.D. Strategi Komunikasi Pemasaran Dinas Pariwisata Dan Kebudayaan Kabupaten Jepara Dalam Meningkatkan Jumlah Pengunjung Pantai Tirta Samudra. eJournal Mahasiswa Universitas Diponegoro Semarang.

Sugiyono. (2016). Memahami Penelitian Kualittatif. Bandung: Alfabeta.

Sugiyono. (2014). Memahami Penelitian Kualitatif. Bandung: Alfabeta.

Tandungan, Y.N. (2016). Strategi Komunikasi Pemasaran Dinas Kebudayaan Dan Pariwisata Kabupaten Tana Toraja Dalam Meningkatkan Jumlah Kunjungan Wisatawan Di Tana Toraja. Skripsi pada Universitas Hasanuddin Makassar: tidak dipublikasikan.

Tiono, Pras. (2015). Strategi Komunikasi Dinas Kebudayaan Pariwisata Pemuda Dan Olahraga Dalam Mempromosikan Objek Wisata Pulau Jemur Di Rokan Hilir. JOM FISIP Volume 2. 
Ulfatin, Nurul. (2013). Teori Penelitian Kualitatif di Bidang Pandidikan: Teori dan Aplikasinya. Bayumeda Publishing: Malang.

Wulanningsih, I. S. (2017). Strategi Komunikasi Pemasaran Dinas Pariwisata Provinsi Riau Dalam Meningkatkan Wisata Melalui Ajang Bujang Dara. Skripsi pada Universitas Telkom Bandung: tidak dipublikasikan.

Yoeti, Oka. (1996). Pengantar Ilmu Pariwisata. Bandung: CV Angkasa.
Yuliani. (2013). Strategi Komunikasi Dinas Kebudayaan Pariwisata Dan Kominfo (Disbudpar) Dalam Meningkatkan Kunjungan Wisatawan Di Desa Pampang Kota Samarinda . eJournal llmu Komunikasi, 2013, 1 (3): 450-464.

Zahro, D.F (2012). Strategi Komunikasi Pemasaran Terpadu Desa Wisata Dalam Meningkatkan Kunjungan Wisatawan. Skripsi pada Universitas Islam Nusantara Sunan Kalijaga Yogyakarta: tidak dipublikasikan. 